\title{
The Mechanism of Insulin-induced Signal Transduction Mediated by the Insulin Receptor Substrate Family
}

\author{
YASUSHI KABURAGI, TOSHIMASA YAMAUCHI, RITSUKO YAMAMOTO-HONDA, KOHJIRO UEKI, \\ KAZUYUKI TOBE, YASUO AKANUMA*, YoSHIO YAZAKI AND TAKASHI KADOWAKI
}

The Third Department of Internal Medicine, Faculty of Medicine, University of Tokyo, Tokyo 113-8655, and

*The Institute for Diabetes Care and Research, Asahi Life Foundation, Tokyo 100-0005, Japan

\begin{abstract}
Distinct from other growth factor receptors, insulin and insulin-like growth factor-I (IGF-I) receptors phosphorylate endogenous substrates on tyrosine residues which in turn associate with the $\mathrm{SH} 2$ domain-containing proteins transducing signals to downstream pathways. Among the cellular substrates of insulin and IGF-I receptors, insulin receptor substrate (IRS)-1 has been shown to play an important role in mediating the actions of these hormones. Recently, several proteins with similar structures and different tissue distributions were cloned as IRS-2, -3 and -4 . To study the roles of these IRSs in mediating insulin actions, we analyzed liver, muscle and adipocytes, the major targets of insulin actions, from IRS-1 null mice which we previously generated, and showed that: 1) insulin-stimulated activation of PI 3-kinase, mitogen-activated protein kinase and glucose transport were impaired in muscles from IRS-1 null mice which was in contrast to the grossly normal signaling and actions in livers from these mice; 2) the difference in the degree of insulin resistance in these two major insulin targets appeared to depend on the amount of tyrosine phosphorylation of IRS-2 compensating for IRS-1 deficiency; 3) insulin-induced activation of PI 3-kinase, glucose transport and GLUT4 translocation were impaired but not abolished in adipocytes from these mice in which IRS-3 was the major tyrosinephosphorylated protein activating PI 3-kinase and at least partially mediating some residual insulin actions in the absence of IRS-1. These data suggest that the members of the IRS family redundantly regulate insulin actions in each target organ in a distinct fashion.
\end{abstract}

Key words: Insulin, Insulin-like growth factor-I, Tyrosine kinase, Insulin receptor substrate, Insulin resistance

(Endocrine Journal 46: S25-S34, 1999)

\section{Endogenous Substrates for Insulin and IGF-I Receptor Kinase}

Insulin binding to its receptor leads to the activation of the receptor tyrosine kinase activity which was discovered in 1982 [1]. This process was considered to be one of the candidates for insulin's signal transduction systems, and many laboratories tried to find the endogenous substrates of the insulin

Correspondence to: Dr. Takashi KADOWAKI, Third Department of Internal Medicine, Faculty of Medicine, University of Tokyo, 7-3-1 Hongo, Bunkyo-ku, Tokyo 1138655, Japan . receptor which may link insulin's signal to its effectors. One of these substrates was pp185 which was detected with antiphosphotyrosine antibody in insulin-treated hepatoma cells as a phosphotyrosinecontaining protein of relative Mr 185,000 [2]. pp185 was considered to be important for the signal transduction of insulin, because: 1) tyrosine phosphorylation of pp185 reaches its maximum within $30 \mathrm{sec}$ after insulin treatment and exhibits a dose-response curve similar to that of receptor autophosphorylation; 2) pp185 is tyrosine phosphorylated in physiological targets of insulin such as liver, muscle and adipocytes [3-5]. Moreover, we showed that pp185 is also tyrosine phosphorylated with IGF-I which was demonstrated 
to occur via the IGF-I receptor but not the insulin receptor by using specific antisera to these receptors $[3,6]$. Therefore the tyrosine-phosphorylation of pp185 was considered to be important for the signal transduction of insulin and IGF-I.

\section{The Structure of Insulin Receptor Substrate-1 (IRS-1)}

pp185 was cloned as insulin receptor substrate (IRS)-1 in 1991 by White and colleagues [7]. IRS-1 contains 21 potential tyrosine phosphorylation sites and over 30 potential serine/threonine phosphorylation sites. In its amino terminus, IRS1 contains a pleckstrin-homology $(\mathrm{PH})$ domain and phosphotyrosine-binding (PTB) domain. The analyses of mutant IRS- 1 with the deletion of the $\mathrm{PH}$ domain revealed that this domain is required for the in vivo interaction between IRS-1 and the insulin receptor [8-10]. Moreover, several studies with the two-hybrid system demonstrated that the PTB domain of IRS-1 interacts with the juxtamembrane NPXY motif of the receptors for insulin and IGF-1 [11-13] so that these two amino terminal domains are considered to be important for the interaction with insulin and IGF-I receptors but not for transducing signals to downstream pathways. Among the multiple potential tyrosine phosphorylation sites in the COOH region of IRS1, there are 6 YMXM motifs and three YXXM motifs both of which are binding sites for the $85 \mathrm{kDa}$ subunit of phosphatidylinositol (PI) 3-kinase (p85). In addition, IRS-1 possesses the tyrosine phosphorylation sites recognized by other src homology (SH) 2 domain-containing proteins such as Grb2 and Syp, indicating that these SH2 domaincontaining molecules mediate multiple insulin actions by interacting with tyrosine-phosphorylated IRS-1 thereby transducing signals to downstream pathways [14-16]. PI 3-kinase activated by interaction with tyrosine-phosphorylated IRS-1 has been shown to be involved in insulin-induced glucose transport and glycogen synthesis by various methods inhibiting the activity of this enzyme [1720]. Moreover, several reports have shown that insulin stimulation causes the association of IRS-1 with PI 3-kinase thereby targeting this enzyme to GLUT4-containing vesicles, which may explain why insulin, but not other growth factors such as platelet-derived growth factor, stimulates glucose transport [21-23]. Grb2 binds to tyrosinephosphorylated IRS-1 via its $\mathrm{SH} 2$ domain and associates via its $\mathrm{SH} 3$ domains with Son of sevenless (Sos), a guanine nucleotide exchange factor of p21 ras, which activates $\mathrm{p} 21^{\text {ras }}$ [24-27], indicating that the pathways mediated by IRS- 1 may activate $21^{\text {ras }}$ and downstream MAP kinase cascade $[28,29]$. IRS1 has binding sites for other signaling molecules although the physiological significance remains to be investigated $[30,31]$.

\section{Mild Insulin Resistance and Growth Retardation in IRS-1 Null Mice}

The role of IRS-1 in insulin-induced signal transduction was suggested by several experimental findings. In Chinese hamster ovary cells overexpressing mutant insulin receptors, insulin actions appear to be parallel with the extent of the tyrosine phosphorylation of IRS-1 rather than that of the receptor itself $[32,33]$. Overexpression of IRS-1 in 32D cells enhances DNA synthesis stimulated by insulin and insulin-like growth factor [34]. In order to understand the roles of IRS-1 in normal physiology, we and other investigators made mice with a targeted disruption of the IRS-1 gene locus [35, 36]. The growth of the homozygous mutant mice was retarded and the weight was about $30 \%$ less than that of normal littermates. The drop of blood sugar after injection of insulin was significantly smaller in homozygous mutant mice than in heterozygous mutant or wild-type mice. There was no significant difference among the three genotypes in the levels of blood glucose after uptake of glucose, but serum insulin levels before and after oral glucose load were significantly higher in the homozygous mutant mice than in heterozygous mutant or wild-type mice. These results showed that IRS-1 is required at least in part for the growth promoting effect and glucose-lowering effect of insulin, but the growth retardation of IRS-1 null mice was milder than that of IGF-I knockout mice [37]. Moreover, both insulin resistance and growth retardation of the IRS-1 knockout mice were milder than those of insulin receptor knockout mice or leprechaunism, the human insulin receptor deficient state $[38,39]$, so that these data strongly suggest the presence of both IRS-1-dependent and independent pathways in signal transduction through insulin and IGF-I receptors. 


\section{IRS-1-independent Pathways Mediated by IRS-1-related Molecules}

In order to identify these IRS-1-independent pathways, we studied insulin-stimulated tyrosinephosphorylated proteins in livers of wild-type and IRS-1 knockout mice (Fig. 1) [40]. We observed a 160-kDa tyrosine-phosphorylated protein in liver of wild-type mice which was revealed to be IRS-1 by immunoprecipitation with the specific antibody. In addition, another $190-\mathrm{kDa}$ tyrosinephosphorylated protein (pp190) was observed, and this protein was not recognized by anti-IRS-1 antibody. In IRS-1 knockout mice, tyrosine phosphorylation of pp190 was enhanced to a degree comparable to that of IRS-1 in wild-type mice, suggesting that this protein may compensate for the absence of IRS-1. Next we examined whether pp190 binds to SH2 domain-containing proteins. In liver from insulin-injected wild-type mice we observed a $160-\mathrm{kDa}$ protein corresponding to IRS1 in the anti-p85 immunoprecipitates. We also observed a weak band of a 190-kDa tyrosinephosphorylated protein in this lane. In contrast, in insulin-injected liver from IRS-1 knockout mice the amount of pp190 immunoprecipitated with antip85 antibody was increased as compared with that in wild-type mice. Similar to the association with p85, the amount of pp190 immunoprecipitated with anti-Grb2 antibody was enhanced in insulin-injected liver from IRS-1 knockout mice. These data suggested that pp190, which was cloned by Sun et al. [41] and named IRS-2, may substitute for IRS-1 in IRS-1 knockout mice by associating with $\mathrm{SH} 2$ domain-containing proteins such as $\mathrm{p} 85$ and Grb2.

\section{Insulin-induced Signaling Pathways Are Different in the Insulin Target Organs from IRS-1 Null Mice}

In order to compare the effect of IRS-1 deficiency in the target organs of insulin, we investigated the insulin-induced signaling pathways and biological actions in livers and muscles from wildtype and IRS-1 null mice [42]. As mentioned above, tyrosine phosphorylation of pp190 in livers from IRS-1 null mice was enhanced to almost the same degree as that of IRS-1 in livers from wild-

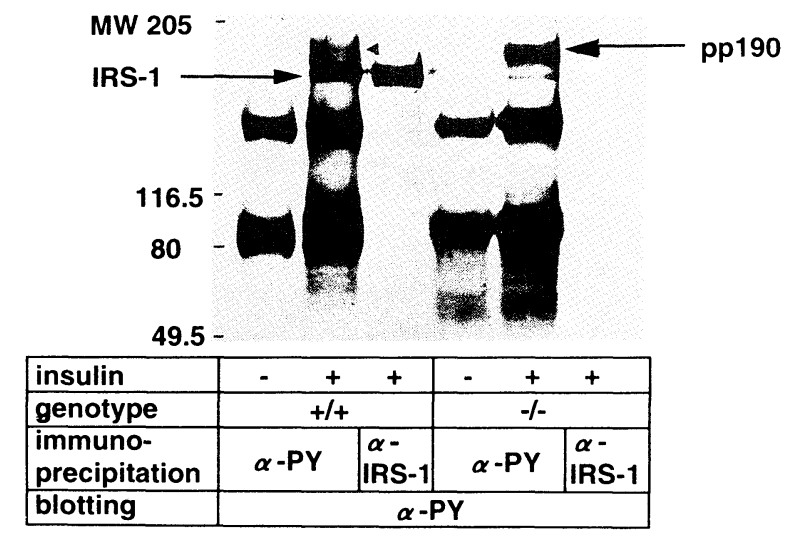

Fig. 1. Detection of pp190 in insulin-injected wild-type or IRS-1 null mice. Wild-type or IRS-1 null mice were injected with saline or insulin via the portal vein. At $75 \mathrm{sec}$, the livers were removed, homogenized and centrifuged. The supernatants were subjected to immunoprecipitation with $\alpha$ PY or $\alpha$ IRS- 1 followed by immunoblotting with RC20.

type mice (Figs. 1 and 2). In contrast, in muscles from these mice tyrosine phosphorylation of IRS-2 was much less $(20-30 \%)$ than that of IRS-1 in muscles from wild-type mice (Fig. 2). This 190$\mathrm{kDa}$ tyrosine-phosphorylated protein was recognized by anti-IRS- 2 antibody and was identified as IRS-2 which was originally found to be a common substrate for interleukin- 4 and insulin receptors in myeloid cell lines. In order to examine whether IRS-2 plays an important role in insulininduced signal transduction in IRS-1 null mice, we evaluated the signaling components and biological actions which were considered to be downstream of IRS- 2 in these mice. In muscles from IRS-1 null mice, MAP kinase activity was significantly decreased compared with that from wild-type mice. In contrast, in livers from these mice, MAP kinase activity was comparable to that in livers from the wild-type mice (Fig. 3). Similar to MAP kinase activity, in muscles from IRS-1 null mice PI 3-kinase was significantly decreased to $20-30 \%$ of that from wild-type mice. In contrast, in livers from these mice, PI 3-kinase activity was comparable to that from the wild-type mice (Fig. 4). The degree of stimulation of 2-deoxyglucose uptake in muscles from IRS-1 null mice was $50 \%$ of that in wild-type mice. 4E-BP1 binds to eukaryotic initiation factor$4 \mathrm{E}$ and inhibits the initiation of the translation of mRNA. It has been shown that insulin stimulates the phosphorylation of $4 \mathrm{E}-\mathrm{BP} 1$ and causes its 

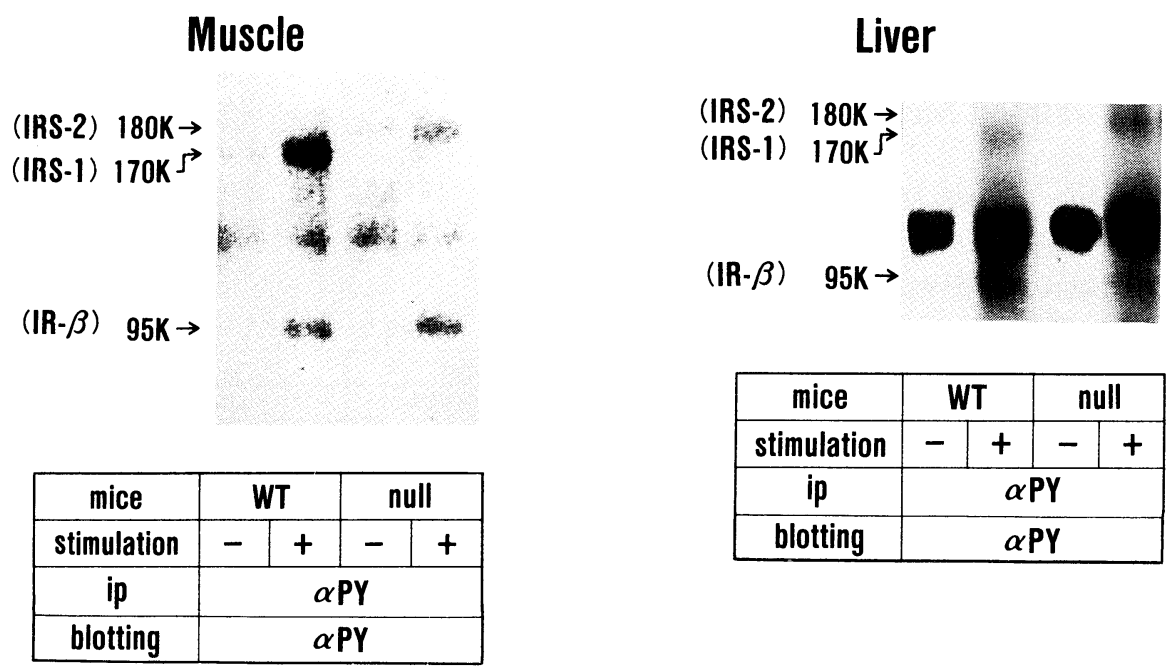

Fig. 2. Insulin-stimulated, tyrosine-phosphorylated proteins in the muscles and livers of wild-type and IRS-1 null mice. Wild-type or IRS-1 null mice were injected with saline or insulin via the portal vein. At $2 \mathrm{~min}$, the skeletal muscles and livers were removed, homogenized and centrifuged. The supernatants were subjected to immunoprecipitation with $\alpha$ PY or $\alpha$ IRS-1 followed by immunoblotting with $\alpha$ PY.

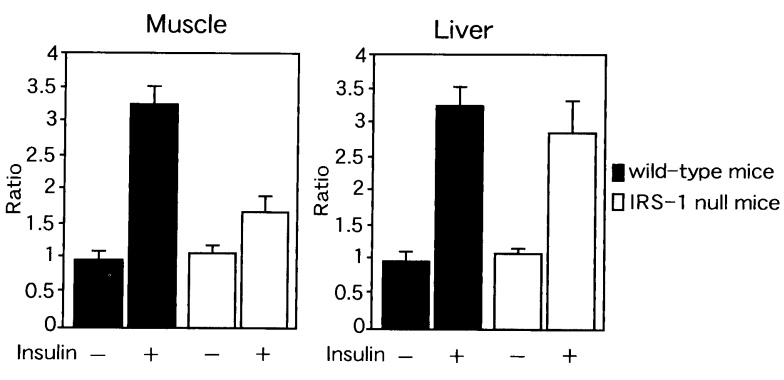

Fig. 3. Insulin-stimulated MAP kinase activity in the muscles and livers of wild-type and IRS-1 null mice. Wild-type or IRS-1 null mice were injected with saline or insulin via the portal vein. At $5 \mathrm{~min}$, the skeletal muscles and livers were removed, homogenized and centrifuged. The supernatants were subjected to immunoprecipitation with the antibody to MAP kinase $(\alpha C 92)$ and then to a kinase assay against MBP.

dissociation from eukaryotic initiation factor- $4 \mathrm{E}$ which enhances protein synthesis [43, 44]. In addition, p70 S6 kinase is shown to phosphorylate ribosomal S6 protein and stimulate the translation of mRNA [45]. Both 4E-BP1 phosphorylation and p70 66 kinase activation have been demonstrated to be regulated by PI 3-kinase [18, 46]. The activation of p70 S6 kinase was significantly impaired in muscles from IRS-1 null mice. An insulin-induced band shift of 4E-BP1, which represents its phosphorylation, was observed in muscles from wild-type mice (Fig. 5), but this response was significantly smaller in those from IRS-1 null mice. In addition, insulin-induced protein synthesis was also impaired in muscles from these mice. These data therefore indicate that in liver the amount of IRS-2 is comparable to that of IRS-1, and IRS-2 almost completely compensates for IRS-1 deficiency, whereas in muscles, a small amount of IRS-2 causes impaired insulin signaling and actions such as activation of PI 3-kinase and MAP kinase, glucose transport, glycogen synthesis and protein synthesis.

In insulin-treated adipocytes, the major band of the $170-\mathrm{kDa}$ tyrosine-phosphorylated protein corresponding to IRS-1 was observed only in adipocytes from wild-type mice, whereas the weak band of the 190-kDa tyrosine-phosphorylated protein corresponding to IRS-2 was detectable in adipocytes from both mouse types. In contrast, the major band of an approximately $60-\mathrm{kDa}$ tyrosine-phosphorylated protein which was recently cloned as IRS-3 [47] was observed in adipocytes from both wild-type and IRS-1 null mice in almost equal amounts [48] (Fig. 6). These results indicated that IRS-3, but not IRS-2, was the major insulin-induced phosphotyrosine-containing protein in adipocytes from IRS-1 null mice. The insulin-stimulated PI 3-kinase activity in 
Muscle
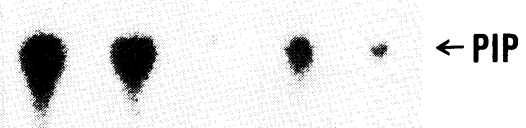

$\leftarrow$ origin

\section{Liver}

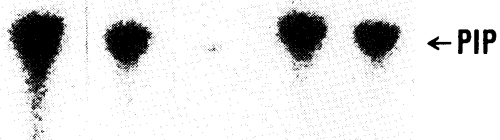

\begin{tabular}{|c|c|c|c|c|c|c|}
\hline mice & \multicolumn{3}{|c|}{ WT } & \multicolumn{3}{c|}{ null } \\
\hline time(min) & 0 & 2 & 5 & 0 & 2 & 5 \\
\hline
\end{tabular}

\begin{tabular}{|c|c|c|c|c|c|c|}
\hline mice & \multicolumn{3}{|c|}{ WT } & \multicolumn{3}{c|}{ null } \\
\hline time $(\min )$ & 0 & 2 & 5 & 0 & 2 & 5 \\
\hline
\end{tabular}

Fig. 4. Insulin-stimulated PI 3-kinase activity in the immunoprecipitates with $\alpha$ PY from the muscles and livers of wildtype and IRS-1 null mice. Wild-type or IRS-1 null mice were injected with saline or insulin via the portal vein. At the periods indicated, the skeletal muscles and livers were removed, homogenized and centrifuged. The supernatants were subjected to immunoprecipitation with $\alpha$ PY and then to a kinase assay against PI.

p70 S6K

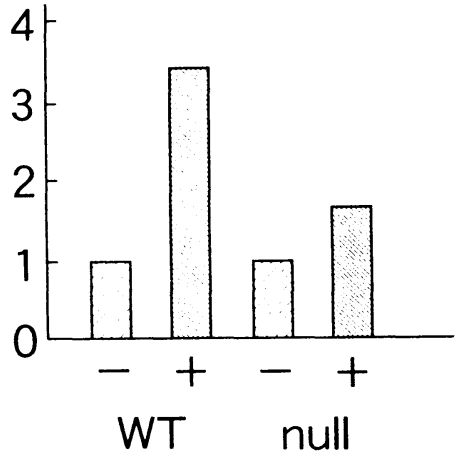

Phosphorylation of 4E-BP1
Protein synthesis

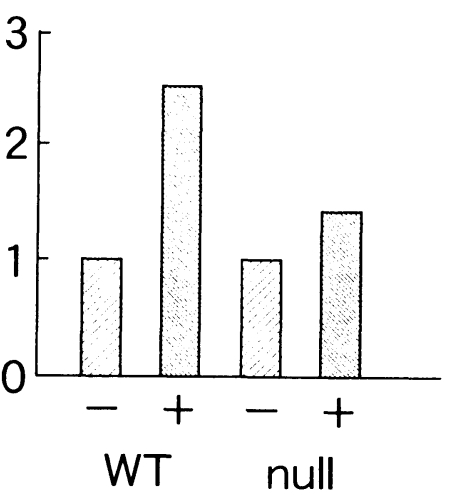

Fig. 5. Insulin-stimulated p70 S6 kinase activity, phosphorylation of 4E-BP1 and protein synthesis in muscles from wild-type and IRS-1 null mice. Muscle extracts from insulin-treated muscles of wild-type and IRS1 null mice were subjected to immunoprecipitation with $\alpha$ p70 S6 kinase followed by a kinase assay (left panel) or to SDS-PAGE followed by immunoblotting with the 4E-BP1 antibody (middle panel). Protein synthesis (right panel) was measured as the incorporation of $\left[{ }^{3} \mathrm{H}\right]$-tyrosine into protein in soleus muscle from wild-type and IRS-1 null mice. 
A
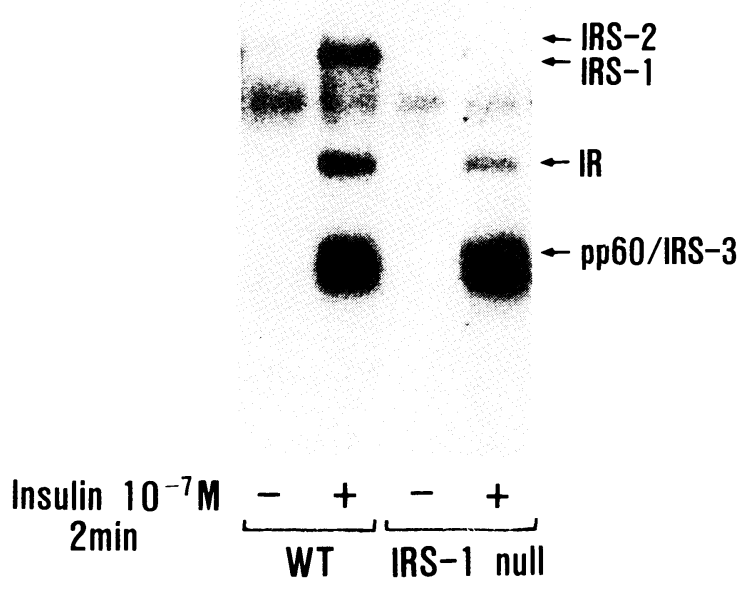

(Kaburagi et al. J. Biol. Chem., 1997)

B

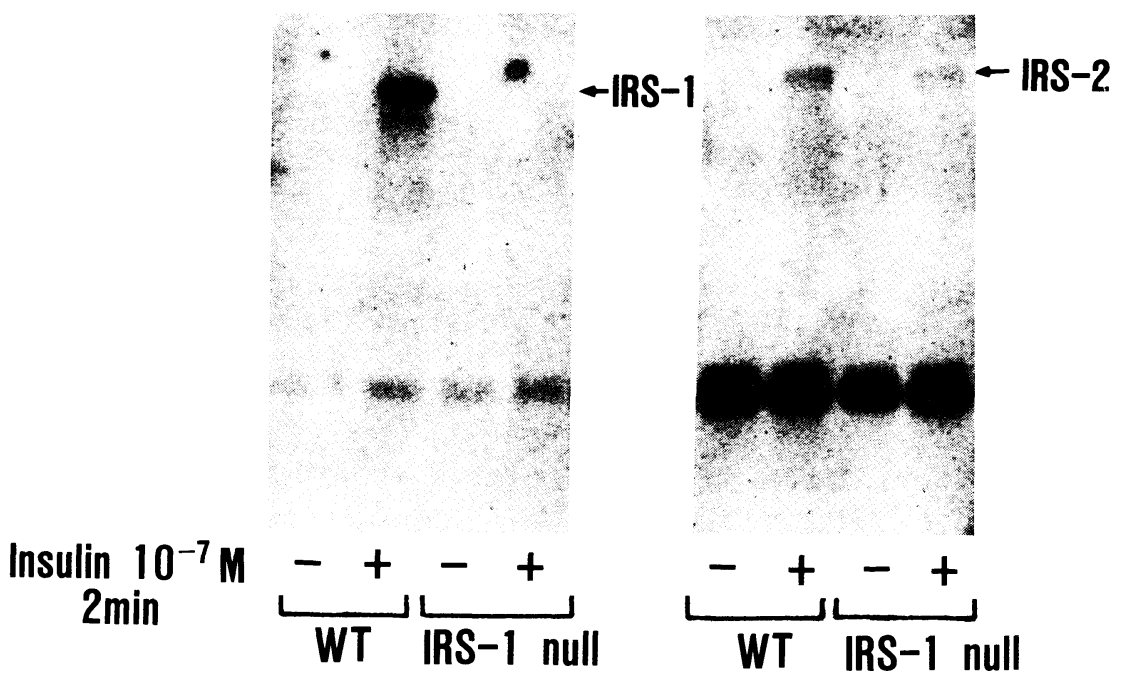

Fig. 6. Insulin-induced phosphotyrosine-containing proteins in intact adipocytes from wild-type (WT) and IRS-1 null mice. After treatment with $10^{-7} \mathrm{M}$ insulin for 2 min, total lysates of isolated adipocytes from wild-type and IRS-1 null mice were immunoprecipitated with $\alpha$ PY (panel A), $\alpha$ IRS-1 (panel B, left panel), or $\alpha$ IRS-2 (panel B, right panel), and were subjected to SDS-PAGE followed by immunoblotting with $\alpha$ PY.

antiphosphotyrosine immunoprecipitates from adipocytes from IRS-1 null mice was approximately $50 \%$ of that from wild-type mice, indicating the presence of other insulin-stimulated tyrosinephosphorylated proteins which can bind and activate PI 3-kinase in adipocytes. By the analysis of phosphotyrosine-containing proteins associated with p85, IRS-3 but not IRS-2 was shown to be a major tyrosine-phosphorylated protein bound to p85 in adipocytes from IRS-1 null mice (Fig. 7). The maximally-stimulated glucose transport in adipocytes from IRS-1 null mice was approximately $50 \%$ of that in cells from wild-type mice. In addition, the half-maximal response in adipocytes from IRS-1 null mice was shifted slightly to the right. These results therefore showed that approximately $50 \%$ of insulin-induced glucose transport activity was preserved by a pathway mediated by signaling proteins other than IRS- 1 . Membrane fractionation and immunoblotting with $\alpha$ Glut4 revealed that the amount of Glut4 translocated to plasma membrane in maximally- 


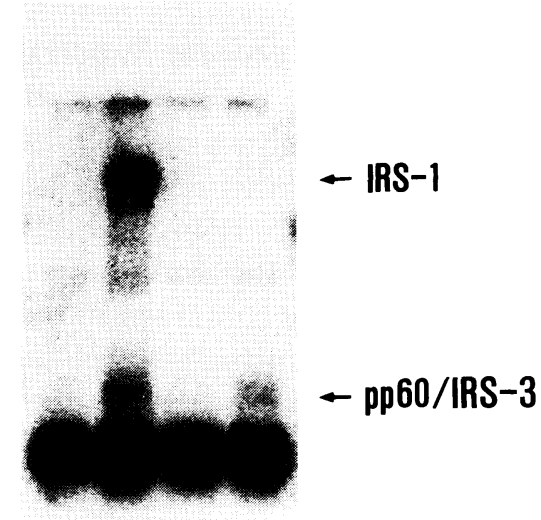

$\underset{2 \min }{\operatorname{Insulin} 10^{-7} \mathrm{M}} \underbrace{-}_{\text {WT }} \underbrace{-}_{\text {IRS-1 null }}$

Fig. 7. Association of PI 3-kinase with phosphotyrosinecontaining proteins from insulin-treated adipocytes. After treatment with $10^{-7} \mathrm{M}$ insulin for $2 \mathrm{~min}$, total lysates of isolated adipocytes from wild-type and IRS-1 null mice were immunoprecipitated with $\alpha p 85$ and subjected to SDS-PAGE followed by immunoblotting with $\alpha P Y$. stimulated adipocytes from IRS-1 null mice was reduced to nearly $70 \%$ of that from wild-type mice (Fig. 8), so that the absence of IRS-1 partially impaired insulin-induced Glut4 translocation and glucose transport in adipocytes. These results suggest that IRS-3 as well as IRS-2 may play a role in mediating insulin-induced signal transduction mediated via PI 3-kinase such as glucose transport in adipocytes from IRS-1 null mice.

Figure 9 shows a summary of the influence of the lack of IRS-1 in the representative target organs of insulin. In muscle, a small amount of IRS-2 led to insufficient compensation for the absence of IRS1. In contrast, tyrosine phosphorylation of IRS-2 in livers was enhanced to almost the same degree as that of IRS-1 in livers from wild-type mice, which caused the grossly normal signaling and actions in livers from these mice. The difference in the degree of insulin resistance in these two major insulin targets from IRS-1 null mice therefore appeared to depend on the amount of tyrosine phosphorylation of IRS-2. Distinct from these two organs, in
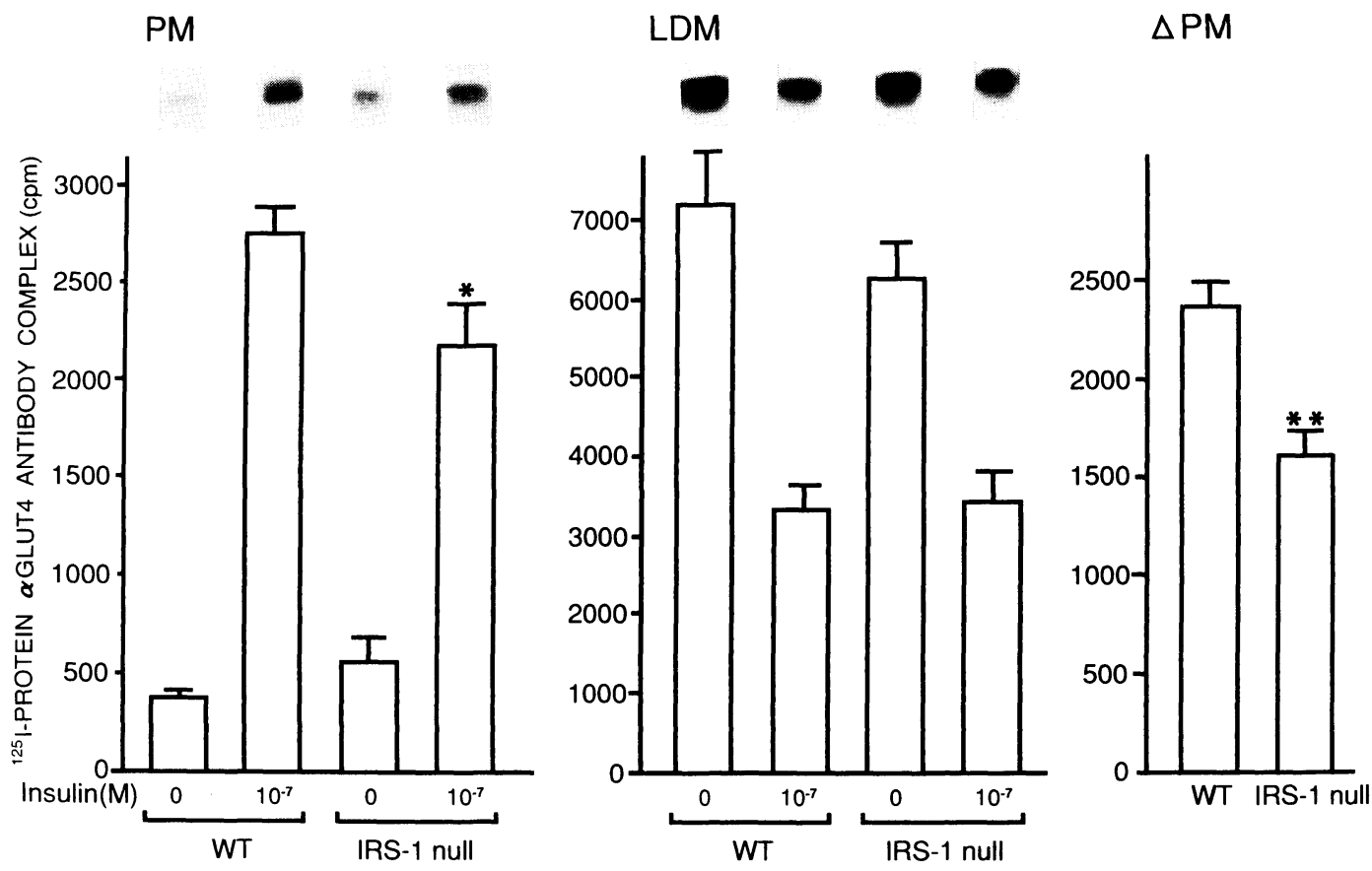

Fig. 8. Subcellular distribution of GLUT4 protein insulin-stimulated adipocytes from wild-type (WT) and IRS-1 null mice. Plasma membrane (PM) and LDM (low density microsome) fractions from adipocytes treated or untreated with $10^{-7} \mathrm{M}$ insulin were prepared, and GLUT4 was immunoblotted with $\alpha$ GLUT4. Autoradiography and quantitation of the amount of GLUT4 in intracellular fractions in adipocytes are shown. The amount of GLUT4 translocated to plasma membrane in response to insulin $(\triangle \mathrm{PM})$ is also shown in this figure. Values are the means and standard errors for three independent experiments. ${ }^{*} P<0.05 v$ s. wild-type; ${ }^{* *} P<0.01 v$ s. wild-type. 


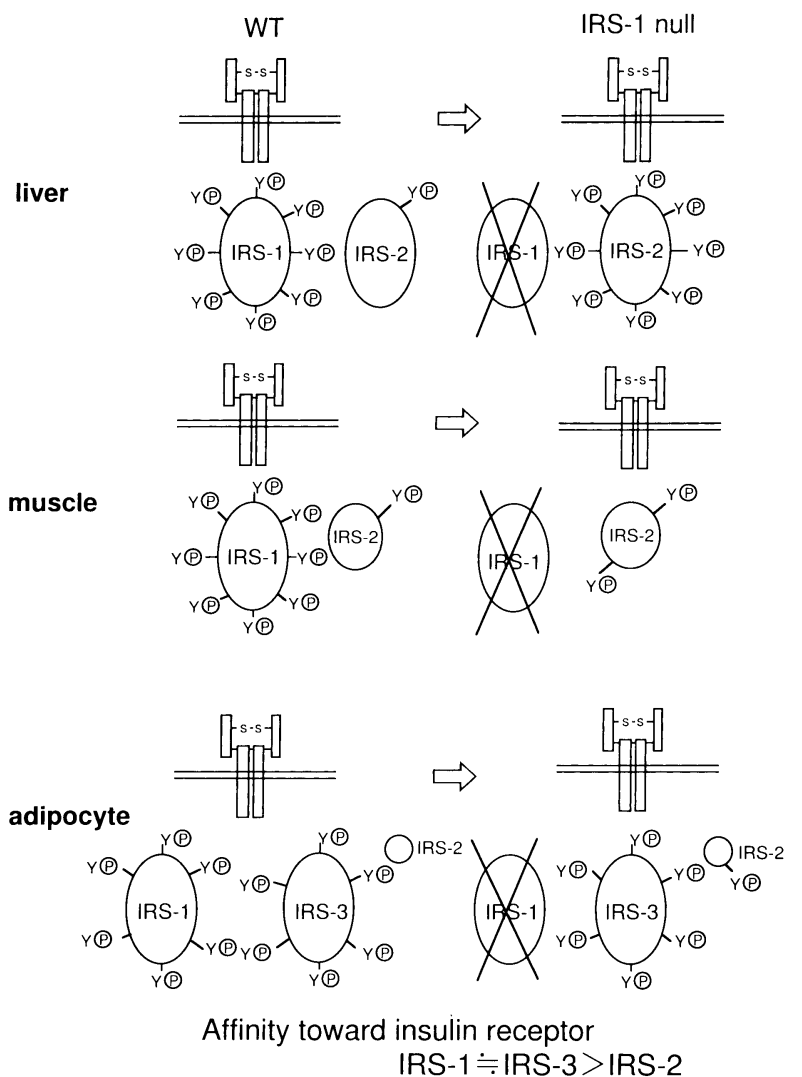

Fig. 9. Different members of the IRS family take part in insulin-induced signal transduction in the three major targets of insulin from IRS-1 null mice.

adipocytes, IRS-3 in addition to IRS- 2 appeared to take part in mediating insulin actions. This may be the reason why insulin-induced glucose transport was not so severely impaired as that in muscles.

\section{Insulin Receptor Substrate Family}

During our analyses of IRS-1 null mice, we noted several molecules which have homology to IRS-1 $[7,41,47,49]$. These molecules, contained in the insulin receptor substrate family, have a similar structure and are contained in the following order from its $\mathrm{N}$ terminus: a $\mathrm{PH}$ domain which is considered to be involved in the interaction with phospholipids, a PTB domain which binds to the phosphotyrosine-containing NPXY motif of the insulin receptor, and the C-terminal domain with a number of tyrosine phosphorylation sites that can bind $\mathrm{SH} 2$ domain-containing proteins. Compared to IRS-1 and IRS-2, the C-terminal domain of IRS-3 is shorter, but it contains one potential Grb2 binding site, four potential binding sites for $\mathrm{p} 85$, and one for Syp or phospholipase $C \gamma$, but the physiological role of each member of this family remains to be investigated.

\section{Conclusions}

The analyses of IRS-1 null mice have verified that: 1) IRS-1 plays a major role in mediating a variety of the biological actions of insulin; 2) The members of the IRS family other than IRS-1 redundantly regulate insulin actions in target organs of insulin in a distinct fashion; 3) Future investigations are required to evaluate the biological significance of the differences among these proteins in functions and localization.

\section{References}

1. Kasuga M, Karlsson FA, Kahn CR (1982) Insulin stimulates the phosphorylation of the 95,000-dalton subunit of its own receptor. Science 215: 185-187.

2. White MF, Maron R, Kahn CR (1985) Insulin rapidly stimulates tyrosine phosphorylation of a Mr-185,000 protein in intact cells. Nature 318: 183-186.

3. Kadowaki T, Koyasu S, Nishida E, Tobe K, Izumi T, Takaku F, Sakai H, Yahara I, Kasuga M (1987) Tyrosine phosphorylation of common and specific sets of cellular proteins rapidly induced by insulin, insulin-like growth factor-I and epidermal growth factor in KB cells. J Biol Chem 262: 7342-7350.
4. Tobe K, Koshio O, Tashiro-Hashimoto $Y$, Takaku F, Akanuma Y, Kasuga M (1990) Immunological detection of phosphotyrosine-containing proteins in rat livers after insulin injection. Diabetes 39: 528533.

5. Momomura K, Tobe K, Seyama Y, Takaku F, Kasuga M (1988) Insulin-induced tyrosine phosphorylation in intact rat adipocytes. Biochem Biophys Res Commun 155: 1181-1186.

6. Izumi $\mathrm{T}$, White MF, Kadowaki T, Takaku F, Akanuma Y, Kasuga M (1987) Insulin-like growth factor I rapidly stimulates tyrosine phosphorylation 
of a Mr 185,000 protein in intact cells. J Biol Chem 262: 1282-1287.

7. Sun XJ, Rothenberg P, Kahn CR, Backer JM, Araki E, Wilden PA, Cahill DA, Goldstein BJ, White MF (1991) Structure of the insulin receptor substrate IRS-1 defines a unique signal transduction protein. Nature 352: 73-77.

8. Myers MG Jr, Grammer TC, Brooks J, Glasheen EM, Wang LM, Sun XJ, Blenis J, Pierce JH, White MF (1995) The pleckstrin homology domain in insulin receptor substrate-1 sensitizes insulin signaling. $J$ Biol Chem 270: 11715-11718.

9. Voliovitch H, Shindler DG, Hadari YR, Taylor SI, Accili D, Zick Y (1995) Tyrosine phosphorylation of insulin receptor substrate-1 in vivo depends upon the presence of its pleckstrin homology region. $J$ Biol Chem 270: 18083-18087.

10. Yenush L, Makati KJ, Smith-Hall J, Ishibashi O, Myers MG Jr, White MF (1996) The pleckstrin homology domain is the principal link between the insulin receptor and IRS-1. J Biol Chem 271: 2430024306.

11. Gustafson TA, He W, Craparo A, Schaub CD, O'Neill TJ (1995) Phosphotyrosine-dependent interaction of SHC and insulin receptor substrate 1 with the NPEY motif of the insulin receptor via a novel non-SH2 domain. Mol Cell Biol 15: 2500-2508.

12. Craparo A, O’Neill TJ, Gustafson TA (1995) NonSH2 domains within insulin receptor substrate-1 and SHC mediate their phosphotyrosine-dependent interaction with the NPEY motif of the insulin-like growth factor I receptor. J Biol Chem 270: 1563915643.

13. He W, O'Neill TJ, Gustafson TA (1995) Distinct modes of interaction of SHC and insulin receptor substrate-1 with the insulin receptor NPEY region via non-SH2 domains. J Biol Chem 270: 23258-23262.

14. Sun XJ, Crimmins DL, Myers MG Jr, Miralpeix M, White MF (1993) Pleiotropic insulin signals are engaged by multisite phosphorylation of IRS-1. Mol Cell Biol 13: 7418-7428.

15. Tobe K, Matuoka K, Tamemoto H, Ueki K, Kaburagi Y, Asai S, Noguchi T, Matsuda M, Tanaka S, Hattori S, Fukui Y, Akanuma Y, Yazaki Y, Takenawa T, Kadowaki $T$ (1993) Insulin stimulates association of insulin receptor substrate-1 with the protein abundant src homology /growth factor receptorbound protein 2. J Biol Chem 268: 11167-11171.

16. Skolnik EY, Lee C-H, Batzer A, Vincentini LM, Zhou M, Daly R, Myers MJ Jr., Backer JM, J Ullrich A, White MF, Schlessinger (1993) The SH2/SH3 domain-containing protein GRB2 interacts with tyrosine-phosphorylated IRS1 and Shc: implications for insulin control of ras signalling. EMBO J 12: 1929-1936.

17. Okada T, Kawano Y, Sakakibara T, Hazeki O, Ui M (1994) Essential role of phosphatidylinositol 3- kinase in insulin-induced glucose transport and antilipolysis in rat adipocytes. Studies with a selective inhibitor wortmannin. J Biol Chem 269: 3568-3573.

18. Cheatham B, Vlahos CJ, Cheatham L, Wang L, Blenis J, Kahn CR (1994) Phosphatidylinositol 3kinase activation is required for insulin stimulation of pp70 S6 kinase, DNA synthesis, and glucose transporter translocation. Mol Cell Biol 14: 49024911.

19. Quon MJ, Chen H, Ing BL, Liu ML, Zarnowski MJ, Yonezawa K, Kasuga M, Cushman SW, Taylor SI (1995) Roles of 1-phosphatidylinositol 3-kinase and ras in regulating translocation of GLUT4 in transfected rat adipose cells. Mol Cell Biol 15: 54035411.

20. Yamamoto-Honda R, Tobe K, Kaburagi $Y$, Ueki K, Asai S, Yachi M, Shirouzu M, Yodoi J, Akanuma Y, Yokoyama S, Yazaki Y, Kadowaki T (1995) Upstream mechanisms of glycogen synthase activation by insulin and insulin-like growth factorI. J Biol Chem 270: 2729-2734.

21. Kelly, K, Ruderman N (1993) Insulin-stimulated phosphatidylinositol 3-kinase. Association with a 185-kDa tyrosine-phosphorylated protein (IRS-1) and localization in a low density membrane vesicle. J Biol Chem 268: 4391-4398.

22. Heller-Harrison RA, Morin M, Czech MP (1995) Insulin regulation of membrane-associated insulin receptor substrate 1. J Biol Chem 270: 24442-24450.

23. Ricort JM, Tanti JF, Van Obberghen E, Le Marchand-Brustel Y (1996) Different effects of insulin and platelet-derived growth factor on phosphatidylinositol 3-kinase at the subcellular level in 3T3-L1 adipocytes. A possible explanation for their specific effects on glucose transport. Eur J Biochem 239: 17-22.

24. Egan SE, Giddings BW, Brooks MW, Buday L, Sizeland AM, Weinberg RA (1993) Association of Sos Ras exchange protein with Grb2 is implicated in tyrosine kinase signal transduction and transformation. Nature 363: 45-51.

25. Li N, Batzer A, Daly R, Yajnik V, Skolnik E, Chardin P, Bar-Sagi D, Margolis B, Schlessinger J (1993) Guanine-nucleotide-releasing factor hSos1 binds to Grb2 and links receptor tyrosine kinases to ras signalling. Nature 363: 85-88.

26. Rozakis-Adcock M, Fernley R, Wade J, Pawson T, Bowtel D (1993) The SH2 and SH3 domains of mammalian Grb2 couple the EGF receptor to the Ras activator mSos1. Nature 363: 83-85.

27. Buday L, Downward J (1993) Epidermal growth factor regulates $\mathrm{p} 21$ ras through the formation of a complex of receptor, Grb2 adaptor protein, and Sos nucleotide exchange factor. Cell 73: 611-621.

28. Yonezawa K, Ando A, Kaburagi Y, YamamotoHonda R, Kitamura T, Hara K, Nakafuku M, 
Okabayashi Y, Kadowaki T, Kaziro Y, Kasuga M (1994) Signal transduction pathways from normal insulin receptors to Ras. J Biol Chem 269: 4634-4640.

29. Chuang L-M, Hausdorff SF, Meyers Jr. MG, White MF, Birnbaum MJ, Kahn CR (1994) Interactive roles of Ras, insulin receptor substrate-1, and proteins with Src homology-2 domains in insulin signaling in Xenopus oocytes. J Biol Chem 269: 27645-27649.

30. Lee $\mathrm{CH}, \mathrm{Li}$ W, Nishimura R, Zhou M, Batzer AG, Myers MG Jr, White MF, Schlessinger J, Skolnik EY (1993) Nck associates with the SH2 domain-docking protein IRS-1 in insulin-stimulated cells. Proc Natl Acad Sci USA 90: 11713-11717.

31. Tobe K, Sabe H, Yamamoto T, Yamauchi T, Asai S, Kaburagi $Y$, Tamemoto $H$, Ueki K, Kimura $H$, Akanuma Y, Yazaki Y, Hanafusa H, Kadowaki T (1996) Csk enhances insulin-stimulated dephosphorylation of focal adhesion proteins. Mol Cell Biol 16: 4765-4772.

32. Kaburagi $Y$, Momomura $K$, Yamamoto-Honda $R$, Tobe K, Tamori Y, Sakura H, Akanuma Y, Yazaki Y, Kadowaki T (1993) Site-directed mutagenesis of the juxtamembrane domain of the human insulin receptor. J Biol Chem 268: 16610-16622.

33. Honda-Yamamoto R, Kadowaki T, Momomura K, Tobe K, Tamori Y, Shibasaki Y, Mori Y, Kaburagi Y, Koshio O, Akanuma Y, Yazaki Y, Kasuga M (1993) Normal insulin receptor substrate-1 phosphorylation in autophosphorylation-defective truncated insulin receptor. J Biol Chem 268: 1685916865.

34. Wang LM, Myers MG Jr, Sun XJ, Aaronson SA, White M, Pierce JH (1993) IRS-1: Essential for insulin- and IL-4-stimulated mitogenesis in hematopoietic cells. Science 261: 1591-1594.

35. Tamemoto H, Kadowaki T, Tobe K, Yagi T, Sakura H, Hayakawa T, Terauchi Y, Ueki K, Kaburagi Y, Satoh S, Sekihara H, Yoshioka S, Horikoshi H, Furuta Y, Ikawa Y, Kasuga M, Yazaki Y, Aizawa S (1994) Insulin resistance and growth retardation in mice lacking insulin receptor substrate-1. Nature 372: 182-186.

36. Araki E, Lipes MA, Patti ME, Bruning JC, Johnson RS, Kahn CR (1994) Alternative pathways of insulin signaling in mice with targeted disruption of the IRS-1 gene. Nature 372: 186-190.

37. Liu JP, Baker J, Perkins A, Robertson EJ, Efstratiadis A (1993) Mice carrying null mutations of the genes encoding insulin-like growth factor I (Igf-1) and type 1 IGF receptor (Igf1r). Cell 75: 59-72.

38. Accili D, Drago J, Lee EJ, Johnson MD, Cool MH, Salvatore P, Asico LD, Jose PA, Taylor SI, Westphal $\mathrm{H}$ (1996) Early neonatal death in mice homozygous for a null allele of the insulin receptor gene. Nature Genetics 12: 106-109.

39. Taylor SI (1992) Molecular mechanisms of insulin resistance. Lessons from patients with mutations in the insulin receptor gene. Diabetes 41: 1473-1490.

40. Tobe K, Tamemoto H, Yamauchi T, Aizawa S, Yazaki Y, Kadowaki T (1995) Identification of a 190$\mathrm{kDa}$ protein as a novel substrate for the insulin receptor kinase functionally similar to insulin receptor substrate-1. J Biol Chem 270: 5698-5701.

41. Sun XJ, Wang LM, Zhang Y, Yenush L, Myers MG Jr, Glasheen E, Lane WS, Pierce JH, White MF (1995) Role of IRS-2 in insulin and cytokine signalling. Nature 377: 173-177.

42. Yamauchi $T$, Tobe $K$, Tamemoto $H$, Ueki $K$, Kaburagi Y, Yamamoto-Honda R, Takahashi Y, Yoshizawa F, Aizawa S, Akanuma Y, Yazaki Y, Kadowaki $T$ (1996) Insulin signalling and insulin actions in the muscles and livers of insulin-resistant, insulin receptor substrate 1-deficient mice. Mol Cell Biol 16: 3074-3084.

43. Lin TA, Kong X, Haystead TA, Pause A, Belsham G, Sonenberg N, Lawrence JC Jr (1994) PHAS-I as a link between mitogen-activated protein kinase and translation initiation. Science 266: 653-656.

44. Pause A, Belsham GJ, Gingras AC, Donze O, Lin TA, Lawrence JCJ, Sonenberg N (1994) Insulindependent stimulation of protein synthesis by phosphorylation of a regulator of 5'-cap function. Nature 371: 762-767.

45. Proud CG (1996) p70 S6 kinase: an enigma with variations. Trends Biochem Sci 21: 181-185.

46. Thomas G, Hall MN (1997) TOR signalling and control of cell growth. Curr Opin Cell Biol 9: 782787.

47. Lavan BE, Lane WS, Lienhard GE (1997) The 60$\mathrm{kDa}$ phosphotyrosine protein in insulin-treated adipocytes is a new member of the insulin receptor substrate family. J Biol Chem 272: 11439-11443.

48. Kaburagi Y, Satoh S, Tamemoto H, YamamotoHonda R, Tobe K, Veki K, Yamauchi T, Kono-Sugita E, Sekihara H, Aizawa S, Cushman SW, Akanuma Y, Yazaki Y, Kadowaki T (1997) Role of insulin receptor substrate-1 and pp60 in the regulation of insulin-induced glucose transport and GLUT4 translocation in primary adipocytes. J Biol Chem 272: 25839-25844.

49. Lavan BE, Fantin VR, Chang ET, Lane WS, Keller SR, Lienhard GE (1997) A novel 160-kDa phosphotyrosine protein in insulin-treated embryonic kidney cells is a new member of the insulin receptor substrate family. J Biol Chem 272: 21403-21407. 